\title{
Soil pollution with copper, lead and zinc in the surroundings of large copper ore tailings impoundment
}

\section{Analiza stopnia zanieczyszczenia miedzią, ołowiem i cynkiem gleb w otoczeniu dużego składowiska odpadów po flotacji rud miedzi}

\begin{abstract}
* Mgr inż. Elżbieta Musztyfaga, prof. dr hab. inż. Cezary Kabała, mgr inż. Agata Urszula Bielińska, mgr inż. Mateusz Cuske, dr inż. Bernard Gałka, Institute of Soil Science and Environmental Protection. Wroctaw University of Environmental and Life Sciences, C. K.Norwida 25 St., 50-375 Wrocław, Poland, e-mail: elzbieta.musztyfaga@up.wroc.pl
\end{abstract}

Keywords: copper, lead, zinc, soil contamination, monitoring, industrial wastes Słowa kluczowe: miedź, ołów, cynk, zanieczyszczenie gleby, monitoring, odpady przemysłowe

\section{Abstract}

Analysis of the top-soil total content of heavy metals was carried out inthe vicinity of large copper ore tailings pound in the southwestern Poland with regard to soil properties, direction and distance from the tailings pound. None of the soils under study exceeded the limits admitted in the official standards for soil quality, but the assessment made in accordance with IUNG-guidelines to soil contamination determination showed that more than half of the monitoring sites have elevated metal content, $\mathrm{Cu}$, in particular. The results confirmed high effectiveness of dust control preventing its eolian spread from the tailings pound.

(c) IOŚ-PIB

\section{INTRODUCTION}

Heavy metals in the soil come from natural and anthropogenic origins. The most important natural origin includes: the soil parent material, atmospheric dusts, including these derived from volcanic eruptions, wet precipitation (in the rain and snow), and the remains of plants and animals (organic matter). Anthropogenic sources include: emissions from industrial facilities, heaps and impoundments, traffic routes, application of mineral fertilizers, wastes, sludge, and composts [Kabata-Pendias et al. 1999].

Heavy metals in soil environment can pose a threat to humans, mainly through the uptake and accumulation in plant tissues. Although some trace metals are microelements necessary for vital functions (e.g. $\mathrm{Zn}$ and $\mathrm{Cu}$ ), their excess may be harmful. Others, like $\mathrm{Pb}$ and $\mathrm{Cd}$, are harmful in any quantity. Heavy metals contribute to rapid or chronic poisoning, and may interfere with the functioning of virtually all of the systems in the human body [Bezak-Mazur 1999].

The tailings pound Żelazny Most is the largest in Poland (and probably in Europe) landfill of the copper ore tailings (from the flotation enrichment), functioning since 1977. It covers an area of about 1500 ha, and its capacity is about 350 million cubic metres. Tailings pound is the object of a potentially large impact on water, soil and atmospheric air [Baran et al. 2013; Czaban et

\section{Streszczenie}

Przeanalizowano całkowitą zawartość metali ciężkich w powierzchniowej warstwie gleb w otoczeniu największego w Polsce składowiska odpadów po flotacji rud miedzi, uwzględniając kierunek i odległość od składowiska oraz podstawowe właściwości gleb. W żadnej z badanych gleb nie zostały przekroczone wartości graniczne dopuszczone w standardzie jakości gleb, natomiast ocena wykonana zgodnie z wytycznymi do oceny stopnia skażenia gleb według IUNG wykazała, że na ponad połowie powierzchni monitoringowych występuje podwyższona zawartość metali, przede wszystkim miedzi. Wyniki potwierdzają dużą skuteczność działań zapobiegających pyleniu ze składowiska.

al. 2000; Dobrzański et al. 1995]. The main source of threat to the quality of air, soil and plants are the fine-grained sediments blown-out from the dry "beaches" in the outer part of the tailings pound. To prevent uncontrolled dusting, the protective action is taken, including spraying the dry beaches with asphalt emulsion, "water curtain" on the embankment during windy and dry weather, etc. [Górski et al. 1995]. The effectiveness of the protective measures is regularly controlled by the system of local monitoring of groundwater, surface water, air, and soil quality [Nierzewska et al. 2007]. The first soil survey in the vicinity of tailings pound was made in 1987 [Kijewski 1995] and the professional monitoring of the soil quality on the permanent observation plots, as well as crop monitoring (in the variable grid) has been run annually since 1996 [Angełow et al. 2000; Kabała et al. 2008; Medyńska et al. 2009].

The purpose of this paper is to analyse the current soil contamination with copper, lead and zinc in the surrounding of the tailings pond, taking into account (i) selected physic-chemical soil properties and (ii) in the context of the limit values set out in Polish legal regulations [Dz.U.2002.165.1359] and (iii) in the IUNG guidelines for the soil contamination assessment [KabataPendias et al. 1995]. 


\section{MATERIALS AND METHODS}

Soil monitoring around tailings pond Żelazny Most (Lower Silesian province, Lubin and Polkowice counties) is run on 64 permanent sites, which are located at a distance of $100 \mathrm{~m}$ to $5 \mathrm{~km}$ from the pond embankment, on arable land, pastures, and forest areas (including the new forest plantations created on the postarable fields). Monitoring sites are arranged in a zone-cluster mode, which means that their density decreases with the distance and is the largest in the nearest zone, and especially in the two villages (two special clusters of sites), potentially the most exposed to the negative impact of the landfill.

Soils surrounded by the landfill are developed mostly of glaciofluvial sands settled during the Warta glaciation (dominant soils are Rubic Arenosols and Podzols), and of glacial loam (dominant soils: Luvisols), as well as of the Holocene alluvial deposits (dominant soils: Fluvisols and Gleysols).

Samples for laboratory analysis were collected in June 2013 using the stainless steel sticks at a depth of 0-30 cm, in accordance with Polish standard of soil quality [Dz.U.2002.165.1359]. Each representative sample consisted of a minimum of five primary samples on arable fields, while in areas recently forested with preserved furrow microrelief [Kabała et al. 2013], it consisted of at least eight primary samples.

The following soil properties were analysed using standard laboratory procedures: particle size distribution - by sieving (sand fraction) and by hydrometer method (silt and clay fractions), following pretreatments to remove organic matter and chemical dispersion with sodium hexametaphosphorate; $\mathrm{pH}$ in distilled water and in $1 \mathrm{M} \mathrm{KCl}$ solution (soil to solution ratio of 1:2.5) - potentiometrically; organic carbon content by the dry combustion method using an automatic apparatus CS-mat 5500. The total concentrations of copper and zinc were measured using atomic absorption spectrophotometry, and lead by inductively coupled plasma in the extracts obtained by sample digestion with aqua regia. The analysis was made in the Institute of Soil Science and Environment Protection at the Wrocław University of Environmental and Life Sciences. Quality of analysis was controlled using the reference soil materials (SRM 2709, SRM 2711, 912, RTH RTH 953) having certified total amounts of the analysed trace elements.

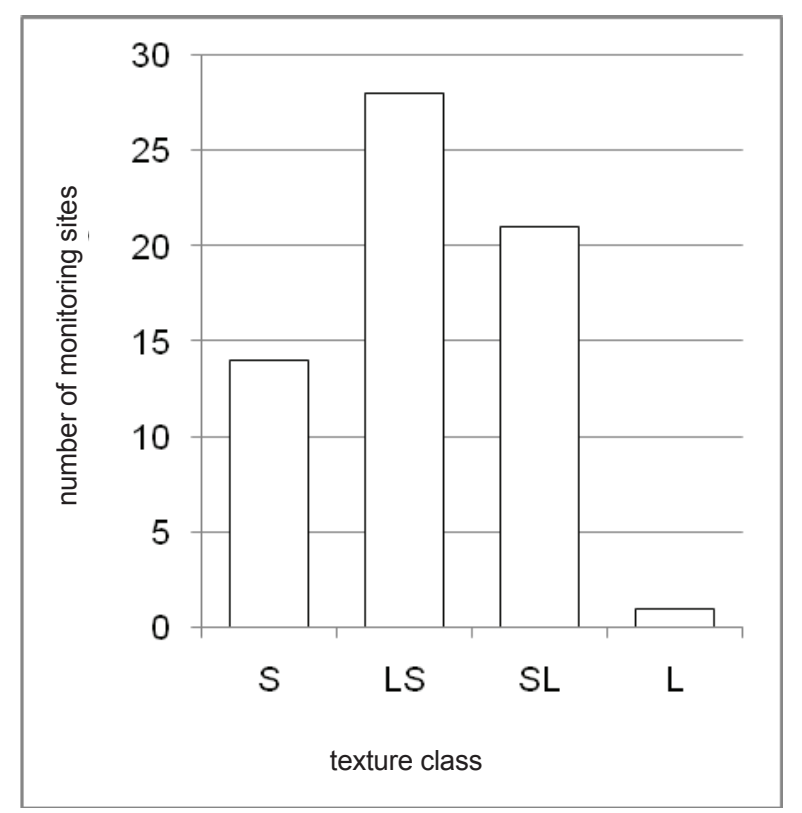

Fig. 1. Distribution chart of topsoil texture classes explanations: S - sand; LS - loamy sand; SL - sandy loam; L - loam.

\section{RESULTS AND DISCUSSION}

Soils surrounding the tailings pond are coarse-textured in general (66\% of cases). Sand and loamy sand texture classes prevail, while sandy loam and loam classes are less common (Fig. 1). Soil $\mathrm{pH}$ was generally weakly acid (Fig. 2), with the range of $\mathrm{pH}_{\mathrm{H} 2 \mathrm{O}}$ value from 5.5 to 7.2 and $\mathrm{pH}_{\mathrm{KCl}}$ from 4.7 to 6.8 . Organic carbon content in top-soil was from $0.9 \%$ to $1.9 \%$; however, organic carbon content was in a narrow range of $1.1-1.5 \%$ in $89 \%$ of the cases (Fig. 3). There is no simple relationship between land use, texture and basic physic-chemical soil properties, as an afforestation involved large areas of former agricultural land situated in the "sanitary zone", irrespective of soil texture and other properties.

Total $\mathrm{Cu}$ content in the topsoil was in the range of 10.5$105 \mathrm{mg} \cdot \mathrm{kg}^{-1}$, with an average at $24.3 \mathrm{mg} \cdot \mathrm{kg}^{-1}$ (Table 1). High values of the standard deviation and variation coefficient (respectively, $15.5 \mathrm{mg} \cdot \mathrm{kg}^{-1}$ and $64 \%$ ) were the largest among studied elements in the soils around the landfill. In more than half of the samples, $\mathrm{Cu}$ content was below $20 \mathrm{mg} \cdot \mathrm{kg}^{-1}$, and the content higher than $100 \mathrm{mg} \cdot \mathrm{kg}^{-1}$ was found in one sample only. The total $\mathrm{Pb}$ content ranged between 11.8 and $45.2 \mathrm{mg} \cdot \mathrm{kg}^{-1}$, averaging $20.3 \mathrm{mg} \cdot \mathrm{kg}^{-1}$, with a variation coefficient of up to $40 \%$ (Table 1). The total Zn content oscillated from 13.4 to $63.1 \mathrm{mg} \cdot \mathrm{kg}^{-1}$, average $27.2 \mathrm{mg} \cdot \mathrm{kg}^{-1}$, with a variation coefficient at $34 \%$. Mean contents of the analysed metals were within the range of concentrations typical in soils of Poland and, generally, were lower than the mean values calculated for the world soils [Kabata-Pendias et al. 1999]. The comparison of the present results and average concentrations from previous years (15-year observation period) indicates that the $\mathrm{Cu}$ and $\mathrm{Zn}$ contents decreased in relation to the level ascertained at the end of the 1990s, and more recently, oscillated at a constant level. In turn, $\mathrm{Pb}$ content reached a minimum during the period 2006-2008 and then began to slowly grow until now [Kabała et al. 2008].

All monitoring sites were located on grounds of B category in accordance with Polish standard of soil quality. Category B includes agricultural lands (arable and meadows, pastures, orchards, etc.), forests and other wooded areas, barren lands, as well as urbanized areas, excluding industrial sites and communication lines

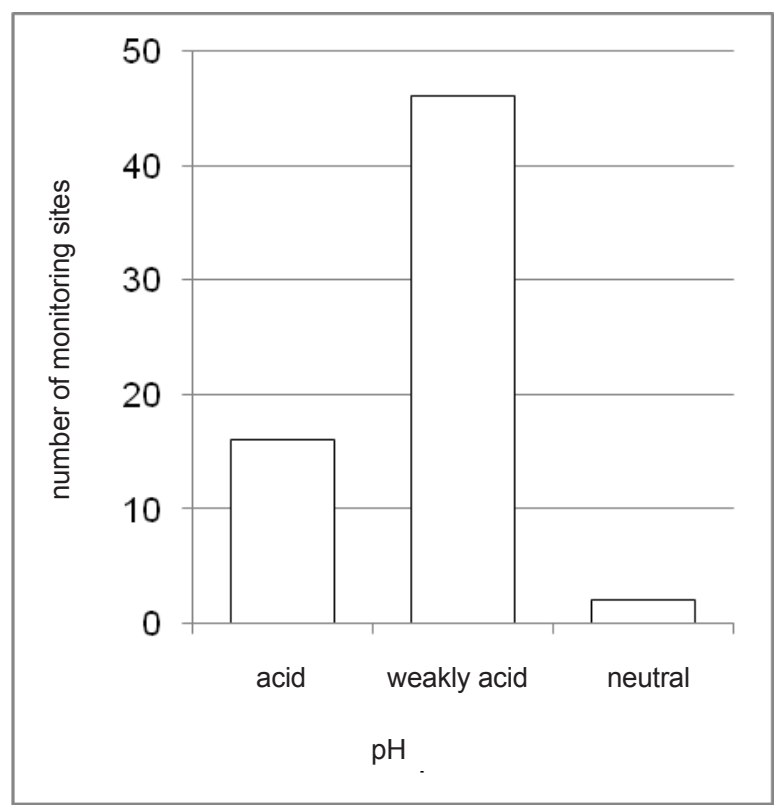

Fig. 2. Distribution chart of topsoil pH 
Table 1. General characteristics of the total content of $\mathrm{Cu}, \mathrm{Pb}$, and $\mathrm{Zn}$ in topsoil around the tailings impoundment

\begin{tabular}{|l|c|c|c|}
\hline Statistical parameter & $\mathrm{Cu}$ & $\mathrm{Pb}$ & $\mathrm{Zn}$ \\
\hline Minimum $\left[\mathrm{mg} \cdot \mathrm{kg}^{-1}\right]$ & 10.5 & 11.8 & 13.4 \\
\hline Maximum $\left[\mathrm{mg} \cdot \mathrm{kg}^{-1}\right]$ & 105.4 & 45.2 & 63.1 \\
\hline Mean $\left[\mathrm{mg} \cdot \mathrm{kg}^{-1}\right]$ & 24.3 & 20.3 & 27.2 \\
\hline Standard deviation $\left[\mathrm{mg} \cdot \mathrm{kg}^{-1}\right]$ & 15.5 & 8.21 & 9.19 \\
\hline Coefficient of variation $[\%]$ & 64 & 40 & 34 \\
\hline
\end{tabular}

[Dz.U.2002.165.1359]. Allowable element contents in the topsoil of lands in category B were established: $\mathrm{Cu}-150 \mathrm{mg} \cdot \mathrm{kg}^{-1}$, $\mathrm{Pb}-100 \mathrm{mg} \cdot \mathrm{kg}^{-1}$, and $\mathrm{Zn}-300 \mathrm{mg} \cdot \mathrm{kg}^{-1}$. The soil is considered contaminated if at least one of the elements exceeded the permissible content.

In none of the investigated soils, the permissible level of the analysed elements was exceeded. Maximum concentration of copper, lead and zinc, respectively, reached $70 \%, 45 \%$ and $21 \%$ of the limit value. In accordance with the legal regulation, this means that the quality of the soils surrounding the landfill met the requirements of the environmental standard, and lack of threats for basic soil functions.

The more precise tool for assessing the degree of soil contamination is the framework guidelines prepared by the Institute of Soil Science and Plant Cultivation (IUNG) [Kabata-Pendias et al 1995], which take into account both the total metal content and soil properties affecting the mobility and bioavailability of metals. Analysis has shown contamination classified from "level 0" (contents considered to be natural) to "level III" in the six-level scale (Table 2). Contamination classified as "level II" and "level III" was found in sandy soils only, and in the case of copper only, whereas "level 0" was the dominant, and "level I" maximal in the case of for $\mathrm{Zn}$ and $\mathrm{Pb}$. The guidelines recommended a resignation from the cultivation of several consumption plants (particularly vegetables) if the soil contamination reached the "level II" and "level III". In this area, all sites, where the "level II" and "level III" of soil contamination occur, have been excluded from the agricultural use and afforested few years ago, so there was no risk of contamination for consumable plants [Chodak et al. 2006].

To more accurately estimate the impact of landfill on soil pollution with heavy metals, their contents were analysed in relation to the distance from the landfill embankment. Cu concentration clearly decreased with the distance, as evidenced by the negative value of the coefficient of correlation, statistically significant at $p<0.05$ (Table 3), whereas $\mathrm{Zn}$ and $\mathrm{Pb}$ were not correlated with the distance to the landfill.

The analysis was enriched with a direction, by dividing the landfill foreland into four sectors: north (N) with 8 monitoring sites, southern (S) with 7 sites, east (E) with 18, and west (W) with 31 sites. The highest mean content of $\mathrm{Cu}$ and $\mathrm{Pb}$ was in sector $\mathrm{E}$, whereas the lowest in sector $S$ (Table 4). Despite the seemingly large differences, mean values do not differ statistically due to the large range of results in each sector. The higher metal concentration in sector $\mathrm{E}$ resulted from the prevailing western direction of winds. Mean $\mathrm{Zn}$ concentration does not differ statistically in the individual sectors with a maximum in sector $\mathrm{W}$ and minimum in sector $\mathrm{N}$.

To illustrate the possible relationship between the direction and distance to the landfill, and the content of metals in the soil, three distance zones were distinguished $(<500,500-1000$, and $>1000 \mathrm{~m}$ from landfill) in sectors $W$ and $E$ where the largest number of monitoring sites is located (Table 5). In both sectors, the Cu content in top-soil decreased as a function of distance from the landfill, and clearly the highest concentrations occurred in the zone $<500 \mathrm{~m}$ in sector $\mathrm{E}$, which clearly confirmed the landfill impact. $\mathrm{Pb}$ content decline in a function of distance in sector $E$ only, whereas no similar trend was observed in sector W. Zinc content in both sectors was lower in the zone $500-1000 \mathrm{~m}$ than in zone $<500 \mathrm{~m}$, but surprisingly grew (and sometimes achieved maximum) in the zone $>1000 \mathrm{~m}$.

Statistical analysis of the relationship between the total metal content and soil properties indicated (Table 3 ) statistically insignificant relationships between the content of clay and organic matter, and the $\mathrm{Cu}$ and $\mathrm{Pb}$ contents. This dependence was commonly found in uncontaminated soils [Kabata-Pendias et al. 1999]. The lack of correlation confirms that another, anthropogenic factor significantly modifies the content of these elements in the analysed area.

Table 2. Percentage of monitoring sites classified to particular levels of soil contamination with $\mathrm{Cu}, \mathrm{Pb}$ and $\mathrm{Zn}$ (according to IUNG guidelines)

\begin{tabular}{|c|c|c|c|}
\hline \multirow{2}{*}{ Soil contamination level } & \multicolumn{4}{|c|}{ Monitoring sites [\% of total number] } \\
\hline O & $\mathrm{Cu}$ & $\mathrm{Pb}$ & $\mathrm{Zn}$ \\
\hline I & 33 & 89 & 97 \\
\hline II & 44 & 11 & 3 \\
\hline III & 19 & 0 & 0 \\
\hline IV & 4 & 0 & 0 \\
\hline V & 0 & 0 & 0 \\
\hline
\end{tabular}

Table 3. Correlation coefficients for $\mathrm{Cu}, \mathrm{Pb}$ and $\mathrm{Zn}$ total concentrations

\begin{tabular}{|l|c|c|c|}
\hline Variable & $\mathrm{Cu}$ & $\mathrm{Pb}$ & $\mathrm{Zn}$ \\
\hline Distance from the landfill & $-0.30^{*}$ & -0.01 & 0.05 \\
\hline Clay $(<0.002 \mathrm{~mm})$ content & 0.14 & 0.09 & $0.35^{*}$ \\
\hline Organic carbon content & 0.20 & 0.23 & $0.27^{*}$ \\
\hline
\end{tabular}

${ }^{*}$ Correlation coefficient significant at $p<0.05$. 


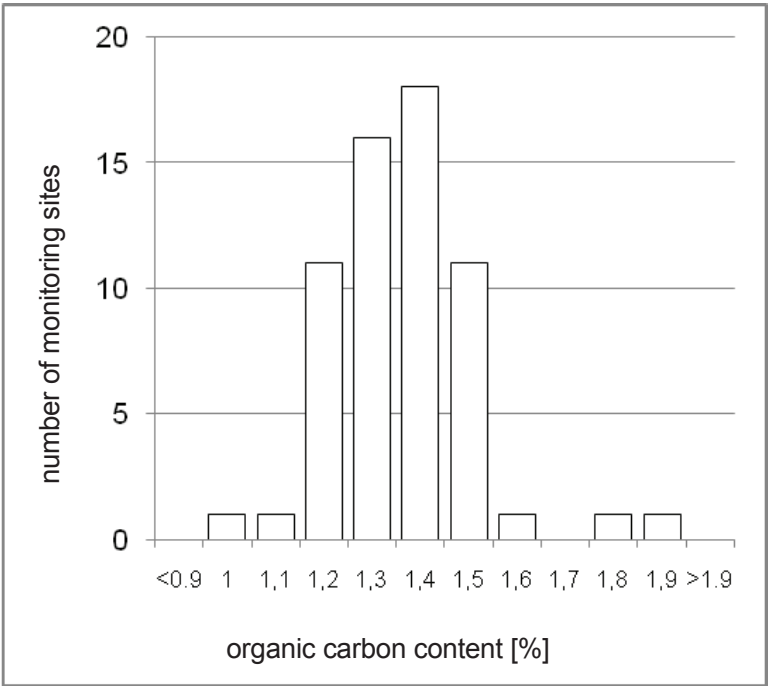

Fig. 3. Distribution chart of topsoil content of organic carbon

On the other hand, both correlations, with the content of the clay and organic matter, were statistically significant in the case of $\mathrm{Zn}$, which clearly showed (in combination with relatively low its total content) that zinc content in the topsoil of the test area is still controlled mainly by natural factors.

\section{SUMMARY}

Despite the large dimension of the tailings pond and long period of operation, its impact on the soil pollution with heavy metals is relatively small, and the mean concentrations of $\mathrm{Cu}, \mathrm{Pb}$ and $\mathrm{Zn}$ are similar to the national averages. In none of the investigated soils, the permissible level of the analysed elements was exceeded, although in accordance with the IUNG guidelines for soil contamination assessment, the content of metals, $\mathrm{Cu}$ in particular, was elevated in more than half of the monitoring sites. Only for $\mathrm{Cu}$, the statistical relation was proven between metal content in soils and the distance from the landfill, which was clearly discernible in the eastern foreland, due to the dominant western direction of winds. Also, the $\mathrm{Pb}$ content was the highest in the eastern foreland and decreases as a function of distance from the landfill. Zinc concentration was not dependent on the direction and distance from the landfill, and was positively correlated with the content of clay and organic matter in soils, confirming the little impact of landfill on the zinc content in topsoil.

Table 4. $\mathrm{Cu}, \mathrm{Pb}$ and $\mathrm{Zn}$ concentrations in the foreland of the landfill

\begin{tabular}{|c|c|c|c|c|}
\hline \multirow{2}{*}{ Sector } & \multirow{2}{*}{ Statistical parameter } & $\mathrm{Cu}$ & $\mathrm{Pb}$ & $\mathrm{Zn}$ \\
\hline & & \multicolumn{3}{|c|}{ Mean content $\left[\mathrm{mg} \cdot \mathrm{kg}^{-1}\right]$} \\
\hline \multirow{3}{*}{$\mathrm{N}$} & Average & 24.7 & 18.6 & 22.8 \\
\hline & Minimum & 13.0 & 13.5 & 16.5 \\
\hline & Maximum & 45.2 & 28.1 & 28.9 \\
\hline \multirow{3}{*}{ S } & Average & 13.7 & 14.7 & 25.5 \\
\hline & Minimum & 10.5 & 11.8 & 18.8 \\
\hline & Maximum & 16.4 & 17.5 & 30.3 \\
\hline \multirow{3}{*}{ W } & Average & 22.3 & 17.7 & 29.8 \\
\hline & Minimum & 11.5 & 12.1 & 13.4 \\
\hline & Maximum & 62.0 & 35.2 & 63.1 \\
\hline \multirow{3}{*}{$E$} & Average & 31.8 & 28.0 & 25.0 \\
\hline & Minimum & 12.4 & 12.1 & 14.6 \\
\hline & Maximum & 105.4 & 45.2 & 46.0 \\
\hline
\end{tabular}

Table 5. $\mathrm{Cu}, \mathrm{Pb}$ and $\mathrm{Zn}$ concentrations in three distance-zones in the east $(\mathrm{E})$ and west $(\mathrm{W})$ sectors of landfill foreland

\begin{tabular}{|c|c|c|c|c|}
\hline \multirow{2}{*}{ Sector } & \multicolumn{3}{|c|}{ Mean content $\left[\mathrm{mg} \cdot \mathrm{kg}^{-1}\right]$} \\
\hline \multirow{3}{*}{ Zone } & & $\mathrm{Cu}$ & $\mathrm{Pb}$ & $\mathrm{Zn}$ \\
\cline { 2 - 5 } & $<500 \mathrm{~m}$ & 27.8 & 17.3 & 30.0 \\
\hline & $500-1000 \mathrm{~m}$ & 20.5 & 17.9 & 27.4 \\
\hline \multirow{2}{*}{$\mathrm{E}$} & $>1000 \mathrm{~m}$ & 19.1 & 17.7 & 33.5 \\
\hline
\end{tabular}

\section{REFERENCES}

ANGEŁOW Z., CHODAK T., KABAŁA C., KASZUBKIEWICZ J., SZERSZEŃ L. 2000. Oddziaływanie zbiornika odpadów poflotacyjnych Żelazny Most na otaczające środowisko glebowe. Roczniki Akademii Rolniczej w Poznaniu. Rolnictwo 56: 327-339
BARAN A., ŚLIWKA M., LIS M. 2013. Selected properties of flotation tailings wastes deposited in the Gilów and Żelazny Most waste reservoirs regarding their potential environmental management. Archives of Mining Sciences 58, 3: 969-978. 
BEZAK-MAZUR E. 1999. Elementy toksykologii środowiskowej. Wydawnictwo Politechniki Świetokrzyskiej, Kielce.

CHODAK T., KASZUBKIEWICZ J., KABAŁA C., SZERSZEŃ L., KOTECKI A., MIKOŁAJCZAK Z., JEZIERSKI D., GAŁKA B., WOŹNICZKA P., OCHMAN D. 2006. Ocena degradacji oraz możliwości zagospodarowania gleb obszaru ograniczonego użytkowania w otoczeniu składowiska odpadów poflotacyjnych Żelazny Most. Zesz. Nauk. Politechniki Śląskiej 1732, Górnictwo 272: 21-30.

CZABAN S., FIAŁKIEWICZ W., KABAŁA C. 2007. Potential impact of tailings pond on crop and forest production. in: J. Wilson (ed.) Environmental Modelling and Simulation. Acta Press, Honolulu: 41-47.

DOBRZAŃSKI J., BYRDZIAK H. 1995. Wpływ polskiego przemysłu miedziowego na środowisko. Zeszyty Problemowe Postępów Nauk Rolniczych 418, 2: 399-405. PAN, Warszawa.

GÓRSKI R., ROZMYSŁOWSKI R., TARASEK W. 1996. Żelazny Most - ochrona środowiska naturalnego na składowisku odpadów poflotacyjnych rud miedzi. Miesięcznik Wyższego Urzędu Górniczego 17: 4-9. Katowice.

KABAŁA C., BOJKO O., MEDYŃSKA A., SZCZEPANIAK A. 2013. Spatial variability and temporal changes in the heavy metal content of soils with a deep furrow-and-ridge microrelief formed by an afforestation plowing. Environmental Monitoring and Assessment 185, 6: 5141-5150.
KABAŁA C., MEDYŃSKAA., CHODAK T., JEZIERSKI P., GAŁKA B. 2008. Zmiany zawartości miedzi i arsenu w glebach wokół składowiska odpadów po flotacji rud miedzi w 12-letnim cyklu badań monitoringowych. Roczniki Gleboznawcze 59, 3-4: 8188. Warszawa.

KABATA-PENDIAS A., PENDIAS H. 1999. Biogeochemia pierwiastków śladowych. Wydawnictwo Naukowe PWN, Warszawa.

KABATA-PENDIAS A., PIOTROWSKA M., POTKOWICKA-TERELAK T., MALISZEWSKA-KORDYBACH B., FILIPIAK K., KRAKOWIAK A., PIETRUCH CZ. 1995. Podstawy oceny chemicznego zanieczyszczenia gleb. Metale ciężkie, siarka i WWA. PIOŚ, IUNG w Puławach, Warszawa.

KIJEWSKI P. 1995. Występowanie metali ciężkich w obszarze środkowego nadodrza w strefie oddziaływania przemysłu miedziowego. Fizykochemiczne Problemy Mineralurgii 29: 47-54. Oficyna Wydawnicza Politechniki Wrocławskiej.

MEDYŃSKA A., KABAŁA C., CHODAK T., JEZIERSKI P. 2009. Concentration of copper, zinc, lead and cadmium in plants cultivated in the surroundings of Żelazny Most copper ore tailings impoundment. Journal of Elementology 14, 4: 729-736.

NIERZEWSKA M., MIZERA A., LEWIŃSKA J. 2007. Wpływ składowiska odpadów poflotacyjnych Żelazny Most na środowisko. Monografia KGHM Polska Miedź S.A., Część VII: Ochrona Środowiska, [red. Piestrzyński A.] : 881-921. Wydawnictwo Profil, Lublin. 